\title{
Salinicoccus iranensis sp. nov., a novel moderate halophile
}

\author{
Mohammad Ali Amoozegar, ${ }^{1}$ Peter Schumann, ${ }^{2}$ Mahbod Hajighasemi, ${ }^{1}$ \\ Morahem Ashengroph ${ }^{1}$ and Mohammad Reza Razavi ${ }^{3}$ \\ ${ }^{1}$ Extremophiles Laboratory, Department of Microbiology, Faculty of Biology, College of Science, \\ University of Tehran, Tehran, Iran \\ ${ }^{2}$ DSMZ - German Collection of Microorganisms and Cell Cultures, Braunschweig, Germany \\ ${ }^{3}$ Pasteur Institute of Iran, Tehran, Iran
}

Correspondence

Mohammad Ali Amoozegar amozegar@khayam.ut.ac.ir
The genus Salinicoccus accommodates aerobic, moderately halophilic bacteria and, at the time of writing, comprised eight species with validly published names: Salinicoccus roseus and Salinicoccus hispanicus (Ventosa et al., 1990, 1992), Salinicoccus alkaliphilus (Zhang et al., 2002), Salinicoccus salsiraiae (França et al., 2006), Salinicoccus jeotgali (Aslam et al., 2007), Salinicoccus luteus (Zhang et al., 2007), Salinicoccus siamensis (Pakdeeto et al., 2007) and Salinicoccus kunmingensis (Chen et al., 2007).

The textile industry produces large quantities of wastewater containing pollutants such as azo dyes and toxic oxyanions that are of major environmental concern. Moderately halophilic bacteria can play an important role in bioremediation and transformation of these toxic compounds in such polluted saline environments. In this study, a toxicoxyanion-tolerant, moderately halophilic, aerobic, Grampositive coccus, designated strain $\mathrm{QW6}^{\mathrm{T}}$, isolated from wastewaters of the textile industry in Qom, Iran, is described on the basis of a polyphasic study. The salinity of the wastewater samples from Qom region was determined to be about $3 \%(\mathrm{w} / \mathrm{v}$, as total salt) and the

Abbreviation: SEM, scanning electron microscopy.

The GenBank/EMBL/DDBJ accession number for the $16 \mathrm{~S}$ rRNA gene sequence of strain $\mathrm{OW6}^{\top}$ is DO767692.
$\mathrm{pH}$ value of the sample was 7.9. Aliquots of the sample were added to $10 \% \mathrm{MH}$ medium (Ventosa et al., 1982) supplemented with sea salts solution as follows $(\%, \mathrm{w} / \mathrm{v})$ : $\mathrm{NaCl}, 8.1 ; \mathrm{MgCl}_{2}, 0.7 ; \mathrm{MgSO}_{4}, 0.96 ; \mathrm{CaCl}_{2}, 0.036 ; \mathrm{KCl}, 0.2$; $\mathrm{NaHCO}_{3}, 0.006$; $\mathrm{NaBr}, 0.0026$; proteose-peptone no. 3, 0.5; yeast extract, 1.0 , and glucose, 0.1 . The $\mathrm{pH}$ was adjusted to 7.5 with $1 \mathrm{M} \mathrm{KOH}$ prior to autoclaving. Incubation was carried out at $35{ }^{\circ} \mathrm{C}$ under aerobic conditions on an orbital shaking incubator (orbital incubator SI 50; Stuart Scientific) at 150 r.p.m. After 2 days incubation, cultures were streaked on agar plates and gave rise to different types of colonies. Pure cultures were isolated after repeated restreaking.

A pure culture of strain $\mathrm{QW6}^{\mathrm{T}}$ was grown and maintained in $10 \% \mathrm{MH}$ medium solidified by adding $15 \mathrm{~g}$ agar (M593 agar) (http://www.dsmz.de/media/med593.htm).

Incubation was carried out on a shaker at 150 r.p.m. and $35^{\circ} \mathrm{C}$. Morphological, physiological and biochemical characteristics of the isolate were studied in $10 \% \mathrm{MH}$ medium at $\mathrm{pH} 7.5$ and $35{ }^{\circ} \mathrm{C}$, unless stated otherwise.

Reference strains S. roseus DSM $5351^{\mathrm{T}}$, S. hispanicus DSM $5352^{\mathrm{T}}$, S. alkaliphilus DSM $16010^{\mathrm{T}}$, S. salsiraiae DSM $19496^{\mathrm{T}}$ and S. kunmingensis DSM $17847^{\mathrm{T}}$ were obtained from the DSMZ. 
Cell morphology was examined by light microscopy and scanning electron microscopy (SEM) using cells from exponentially growing cultures. Strain QW6 ${ }^{\mathrm{T}}$ was prepared for SEM according to the method of Bozzola \& Russell (1999) and specimens were observed on a Zeiss DSM 960 EM. Gram staining was performed by the Burke method (Murray et al., 1994) and the result was confirmed by the KOH test (Baron \& Finegold, 1990). Motility was analysed by the wet-mount method (Murray et al., 1994). Catalase, oxidase and urease activities, nitrate reduction, hydrolysis of aesculin and production of indole were tested as recommended by Smibert \& Krieg (1994). Hydrolysis of Tween 80 was examined as described by Harrigan \& McCance (1976). Methyl red and Voges-Proskauer tests were done as recommended by Smibert \& Krieg (1994). Determination of acid production from carbohydrates, as well as utilization of carbon and nitrogen sources, was performed as recommended by Ventosa et al. (1982).

Antibiotic susceptibility tests were performed on MuellerHinton agar plus $10 \%(\mathrm{w} / \mathrm{v})$ sea salts seeded with a bacterial suspension containing $1.5 \times 10^{6}$ c.f.u. $\mathrm{ml}^{-1}$ using discs (HiMedia) impregnated with various antibiotics. The plates were incubated at $35{ }^{\circ} \mathrm{C}$ for $48 \mathrm{~h}$ and the inhibition zone was interpreted according the manufacturer's manual. To determine the optimal temperature and $\mathrm{pH}$ for growth of the strain, broth cultures were incubated at temperatures of $5-55{ }^{\circ} \mathrm{C}$ at intervals of $5{ }^{\circ} \mathrm{C}$ and at $\mathrm{pH} 5-11$ at intervals of $0.5 \mathrm{pH}$ units. $\mathrm{pH}$ values below $6, \mathrm{pH} 6-9$ and $\mathrm{pH}$ values above 9 were obtained using sodium acetate/acetic acid, Tris/ $\mathrm{HCl}$ and glycine/sodium hydroxide buffers, respectively. Growth at different salt contents $(0,2.5,5,7.5,10,15,20,25$ and $30 \%, w / v$ ) was tested on $\mathrm{MH}$ medium at $\mathrm{pH}$ 7.5. Growth was monitored by turbidity at $\mathrm{OD}_{600}$ using a spectroscopic method (model UV-160 A; Shimadzu). Other physiological and biochemical tests were performed as described previously (Mata et al., 2002; Quesada et al., 1984). As the habitat of the isolate was polluted by toxic compounds such as tellurite, selenite and selenate oxyanions, the resistance of strain QW6 ${ }^{\mathrm{T}}$ to these oxyanions was measured by the agar dilution method of Washington \& Sutter (1980). Melted nutrient agar (20 ml) plus various concentrations of tellurite $(0.1-40 \mathrm{mM})$, selenite $(1 \mathrm{mM}$ to $1 \mathrm{M})$ and selenate $(1 \mathrm{mM}$ to $1.2 \mathrm{M})$ were poured separately into $8 \mathrm{~cm}$ plates. Then, $10 \mu \mathrm{l}$ bacterial suspension $\left(1.5 \times 10^{8}\right.$ c.f.u. $\left.\mathrm{ml}^{-1}\right)$ was inoculated onto each plate using a sampler followed by incubation at $35^{\circ} \mathrm{C}$ for 7 days. Minimum inhibitory concentrations for tellurite, selenite and selenate oxyanions were determined. Each plate was prepared in triplicate.

Preparation and hydrolysis of the cell wall was carried out using the method of Schleifer (1985) and the interpeptide bridge in the cell-wall peptidoglycan was analysed by using the method described by Schleifer \& Kandler (1972). Cellwall hydrolysates were separated by one- or two-dimensional chromatography on cellulose thin-layer plates (Merck).

Isoprenoid quinone analysis was carried out as described by Monciardini et al. (2003). Cellular fatty acids were extracted from cells of strain QW6 ${ }^{\mathrm{T}}$, S. roseus DSM $5351^{\mathrm{T}}$, S. hispanicus DSM $5352^{\mathrm{T}}$, S. alkaliphilus DSM $16010^{\mathrm{T}}$ and S. salsiraiae DSM $19496^{\mathrm{T}}$ that had been cultivated on $10 \%$ $\mathrm{MH}$ medium at $37^{\circ} \mathrm{C}$ for 1 day according to Stead et al. (1992) and were analysed by GC (Groth et al., 1996).

For determination of DNA base composition and DNADNA hybridization, DNA was isolated using a French pressure cell (Thermo Spectronic) and was purified by chromatography on hydroxyapatite as described by Cashion et al. (1977). The DNA G+C content was determined by reversed-phase HPLC of nucleosides according to Mesbah et al. (1989). DNA-DNA hybridization was carried out by the Identification Service of the DSMZ, as described by De Ley et al. (1970) incorporating the modifications described by Huß et al. (1983) using a Cary 100 Bio UV/VIS spectrophotometer equipped with a Peltier-thermostatted $6 \times 6$ multicell changer and a temperature controller with an in situ temperature probe (Varian).

Genomic DNA of the isolate was extracted with a Genelute DNA extraction kit (Sigma) by following the recommended procedure of the manufacturer.

The 16S rRNA gene of the isolate was amplified using universal primers $8 \mathrm{~F}$ ( $5^{\prime}$-AGAGTTTGATCCTGGCTCAG$3^{\prime}$ ) and 1541R (5'-AAGGAGGTGATCCAGCCGCA-3'). The amplification was performed by initial denaturation at $95{ }^{\circ} \mathrm{C}$ for $5 \mathrm{~min}$ followed by: 10 cycles of $93{ }^{\circ} \mathrm{C}$ for $1 \mathrm{~min}, 63{ }^{\circ} \mathrm{C}$ for $1 \mathrm{~min}, 71{ }^{\circ} \mathrm{C}$ for $1.5 \mathrm{~min}$; 20 cycles of $93{ }^{\circ} \mathrm{C}$ for $1 \mathrm{~min}, 6{ }^{\circ} \mathrm{C}$ for $1 \mathrm{~min}, 71{ }^{\circ} \mathrm{C}$ for $2 \mathrm{~min}$; and a final extension at $71{ }^{\circ} \mathrm{C}$ for $5 \mathrm{~min}$. The purified PCR product was sequenced in both directions using an automated sequencer by the SeqLab Laboratory (Göttingen, Germany).

Phylogenetic analysis was performed using the software packages PHYLIP (Felsenstein, 1993) and MEGA version 3

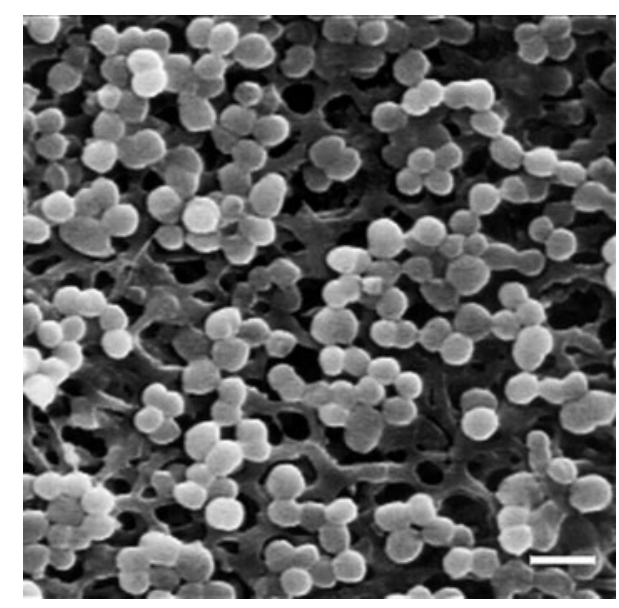

Fig. 1. Scanning electron micrograph of cells of Salinicoccus iranensis sp. nov. $\mathrm{QW}^{\top}$ from an exponentially growing culture. Bar, $2 \mu \mathrm{m}$. 
(Kumar et al., 2004) after multiple alignment of data available from public databases by CLUSTAL_X (Thompson et al., 1997).

Pairwise evolutionary distances were computed using the correction of Jukes \& Cantor (1969) and clustering was performed using the neighbour-joining method (Saitou \& Nei, 1987). Bootstrap analysis was used to evaluate the tree topology of the neighbour-joining data by performing 1000 resamplings (Felsenstein, 1985).

Cells of the novel isolate were Gram-positive, non-sporeforming, non-motile cocci that were strictly aerobic and occurred singly, in pairs, in tetrads or in clumps (Fig. 1). Colonies were round, smooth, entire, opaque and approximately $2 \mathrm{~mm}$ in diameter forming an orangish pink, non-diffusible pigment after 2 days at $35{ }^{\circ} \mathrm{C}$ on $10 \% \mathrm{MH}$ medium. Strain $\mathrm{QW}^{\mathrm{T}}$ grew at sea salts concentrations in the range $1-25 \%(\mathrm{w} / \mathrm{v})$ in $\mathrm{MH}$ medium. Growth did not occur at concentrations of sea salts greater than $25 \%(\mathrm{w} / \mathrm{v})$. The temperature range for growth was $5-45^{\circ} \mathrm{C}$ and the $\mathrm{pH}$ range was 6.5-10.0. Optimal growth occurred in $\mathrm{MH}$ medium supplemented with $7.5-10 \%(\mathrm{w} / \mathrm{v})$ sea salts at $35{ }^{\circ} \mathrm{C}$ and $\mathrm{pH}$ 7.5. The novel isolate was resistant to potassium tellurite, sodium selenite and sodium selenate up to concentrations of 12,600 and $1000 \mathrm{mM}$, respectively.

It must be emphasized that the novel isolate not only tolerated tellurite and selenite, but also reduced these oxyanions. Reduction of tellurite and selenite by this strain resulted in black and dark-red colonies on agar plates due to

Table 1. Comparison of Salinicoccus iranensis sp. nov. with members of the genus Salinicoccus

Species: 1, S. iranensis sp. nov. strain QW6 ${ }^{\mathrm{T}}$; 2, S. roseus DSM $5351^{\mathrm{T}} ; 3$, S. hispanicus DSM $5352^{\mathrm{T}}$; 4, S. alkaliphilus DSM $16010^{\mathrm{T}} ; 5$, S. salsiraiae LMG $22840^{\mathrm{T}}$; 6, S. jeotgali KCTC $13030^{\mathrm{T}}$; 7, S. kunmingensis DSM $17847^{\mathrm{T}}$. Data from Ventosa et al. (1990, 1992), Zhang et al. (2002), Aslam et al. (2007), França et al. (2006), Chen et al. (2007) and this study. ND, No data; D, differs among strains.

\begin{tabular}{|c|c|c|c|c|c|c|c|}
\hline Characteristic & 1 & 2 & 3 & 4 & 5 & 6 & 7 \\
\hline Cell diameter $(\mu \mathrm{m})$ & $0.8-1.0$ & $1.0-2.5$ & $1.0-2.5$ & $0.5-0.8$ & $1.0-2.5$ & $1.0-2.0$ & $0.8-1.2$ \\
\hline Pigmentation & Orangish pink & Pink-red & Reddish orange & Pinkish & Pink-red & Orange & Yellow \\
\hline \multicolumn{8}{|l|}{ Growth in $\mathrm{NaCl}(\%, w / v)$ : } \\
\hline Range & $1.0-25.0$ & $0.5-25.0$ & $0.9-25.0$ & $0-25.0$ & $0-22.0$ & $0.5-15.0$ & $0.5-25.0$ \\
\hline Optimum & $7.5-10.0$ & 10 & 10 & 10 & 4 & 5 & $8-10$ \\
\hline \multicolumn{8}{|l|}{ Growth $\mathrm{pH}$ : } \\
\hline Range & $6.5-10$ & $5.0-9.0$ & $6.0-9.0$ & $6.5-11.5$ & $6.5-9.5$ & $6.5-11.0$ & $6.0-10.0$ \\
\hline Optimum & 7.5 & 7.5 & 8 & 9.5 & 8 & 7 & 8 \\
\hline \multicolumn{8}{|l|}{ Growth temperature $\left({ }^{\circ} \mathrm{C}\right)$ : } \\
\hline Range & $5.0-45.0$ & $15.0-37.0$ & $15.0-40.0$ & $10.0-49.0$ & $20.0-45.0$ & $20.0-30.0$ & $4.0-45.0$ \\
\hline Optimum & 35 & 37 & 37 & 32 & 37 & 30 & 37 \\
\hline \multicolumn{8}{|l|}{ Acid production from: } \\
\hline Fructose & + & - & + & - & + & + & + \\
\hline Galactose & - & - & + & - & - & - & - \\
\hline D-Glucose & + & - & + & + & + & + & - \\
\hline Glycerol & - & - & + & - & + & + & - \\
\hline Maltose & - & - & + & - & + & + & - \\
\hline D-Mannitol & + & - & + & + & - & - & + \\
\hline Sucrose & - & - & D & - & - & - & + \\
\hline \multicolumn{8}{|l|}{ Hydrolysis of: } \\
\hline Aesculin & - & - & + & + & - & + & + \\
\hline Casein & - & + & - & - & + & - & - \\
\hline Gelatin & - & + & + & - & + & - & - \\
\hline Starch & - & + & - & - & - & - & + \\
\hline Tween 80 & - & + & - & - & $\mathrm{ND}$ & - & + \\
\hline Nitrate reduction & + & - & + & + & + & + & + \\
\hline Indole test & + & - & - & - & - & + & - \\
\hline $\mathrm{H}_{2} \mathrm{~S}$ production & - & - & - & - & ND & + & - \\
\hline Methyl red test & - & - & + & - & - & + & - \\
\hline Urease & - & - & + & + & - & - & - \\
\hline Tellurite resistance $(\mathrm{mM})^{\star}$ & 12 & 1 & 4 & 6 & 1 & $\mathrm{ND}$ & 0.5 \\
\hline Selenite resistance $(\mathrm{mM})^{\star}$ & 600 & 200 & 600 & 800 & 200 & $\mathrm{ND}$ & 400 \\
\hline MK-7 & + & + & + & - & ND & + & + \\
\hline DNA G $+\mathrm{C}$ content $(\mathrm{mol} \%)$ & 54.4 & 51.2 & $45.6-49.3$ & 49.6 & 46.2 & 47 & 46.2 \\
\hline
\end{tabular}

${ }^{\star}$ The results of these tests were from our laboratory under identical conditions. 
the accumulation of intracellular crystals of black elemental Te and red, amorphous elemental Se, respectively.

Detailed physiological and biochemical characteristics of the strain are shown in Table 1 and in the species description.

Phenotypic data are compatible with assignment of strain QW6 $^{\mathrm{T}}$ to the genus Salinicoccus (Ventosa et al., 1990, 1992; Zhang et al., 2002, 2007; França et al., 2006; Aslam et al., 2007; Pakdeeto et al., 2007; Chen et al., 2007).

The almost complete 16S rRNA gene sequence (1499 bp) of strain $\mathrm{QW6}^{\mathrm{T}}$ was determined. Alignments of this sequence with sequences belonging to type strains of the halophilic cocci available from GenBank showed that the closest relative of strain $\mathrm{QW6}^{\mathrm{T}}$ was S. roseus DSM $5351^{\mathrm{T}}$, with a sequence similarity of $96.4 \%$. The sequence similarities of strain QW6 ${ }^{\mathrm{T}}$ to S. hispanicus DSM $5352^{\mathrm{T}}$, S. luteus YIM $70202^{\mathrm{T}}$, S. jeotgali KCTC $13030^{\mathrm{T}}$, S. salsiraiae LMG $22840^{\mathrm{T}}$, S. siamensis $\mathrm{PN1} 12^{\mathrm{T}}$, S. alkaliphilus DSM $16010^{\mathrm{T}}$ and $S$. kunmingensis YIM $\mathrm{Y}^{\mathrm{T}} 5^{\mathrm{T}}$ were 95.0, 94.9, 94.5, 94.5, 94.1, 94.0 and $92.9 \%$, respectively. The level of $16 \mathrm{~S}$ rRNA gene sequence similarity between strain QW6 ${ }^{\mathrm{T}}$ and other Gram-positive cocci was less than $91 \%$. The phylogenetic tree constructed by the neighbour-joining method is shown in Fig. 2.

The $\mathrm{G}+\mathrm{C}$ content of strain $\mathrm{QW6}^{\mathrm{T}}$ was $54.4 \mathrm{~mol} \%$. The major isoprenoid quinone of strain $\mathrm{QW6}^{\mathrm{T}}$ was MK-6, although MK-7 and MK-5 were present in trace amounts.

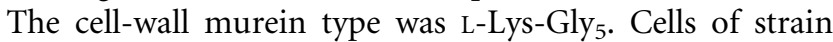
$\mathrm{QW}^{\mathrm{T}}$ and of the type strains of S. roseus, S. hispanicus, $S$. alkaliphilus and S. salsiraiae were cultivated under identical conditions for comparison of the cellular fatty acid content. These data are compiled in Table 2 together with the data for S. jeotgali (Aslam et al., 2007). The fatty acid content of $S$. jeotgali was very similar to those of the other type strains, even though the cells were grown under different conditions. Strain $\mathrm{QW}^{\mathrm{T}}$ had iso- $\mathrm{C}_{15: 0}$ and anteiso- $\mathrm{C}_{15: 0}$ as major fatty acids; most minor fatty acids were similar to those of the type strains of members of the genus Salinicoccus, except that strain $\mathrm{QW6}^{\mathrm{T}}$ had a remarkably higher $\mathrm{C}_{20: 0}$ content.

Based on sequence dissimilarity values $(>3 \%)$, the novel isolate did not belong to any other described species and was likely to represent a novel species of the genus Salinicoccus (Stackebrandt \& Goebel, 1994).

DNA-DNA hybridization experiments revealed low levels of relatedness between strain $\mathrm{QW6}^{\mathrm{T}}$ and S. roseus DSM $5351^{\mathrm{T}}(40.3 \%)$, S. hispanicus DSM $5352^{\mathrm{T}}(1.3 \%)$ and $S$. alkaliphilus DSM $16010^{\mathrm{T}}(19.6 \%)$. According to Wayne et al. (1987), less than $70 \%$ DNA-DNA relatedness is considered to be the threshold value for the delineation of genospecies, so the values are low enough to separate strain QW6 ${ }^{\mathrm{T}}$ from these three species.

The phylogenetic distinctiveness and low DNA-DNA relatedness values, together with several phenotypic differences (physiological and biochemical, as well as DNA G + C content; Table 1), indicate that strain QW6 $^{\mathrm{T}}$ represents a novel species of the genus Salinicoccus, for which the name Salinicoccus iranensis sp. nov. is proposed.

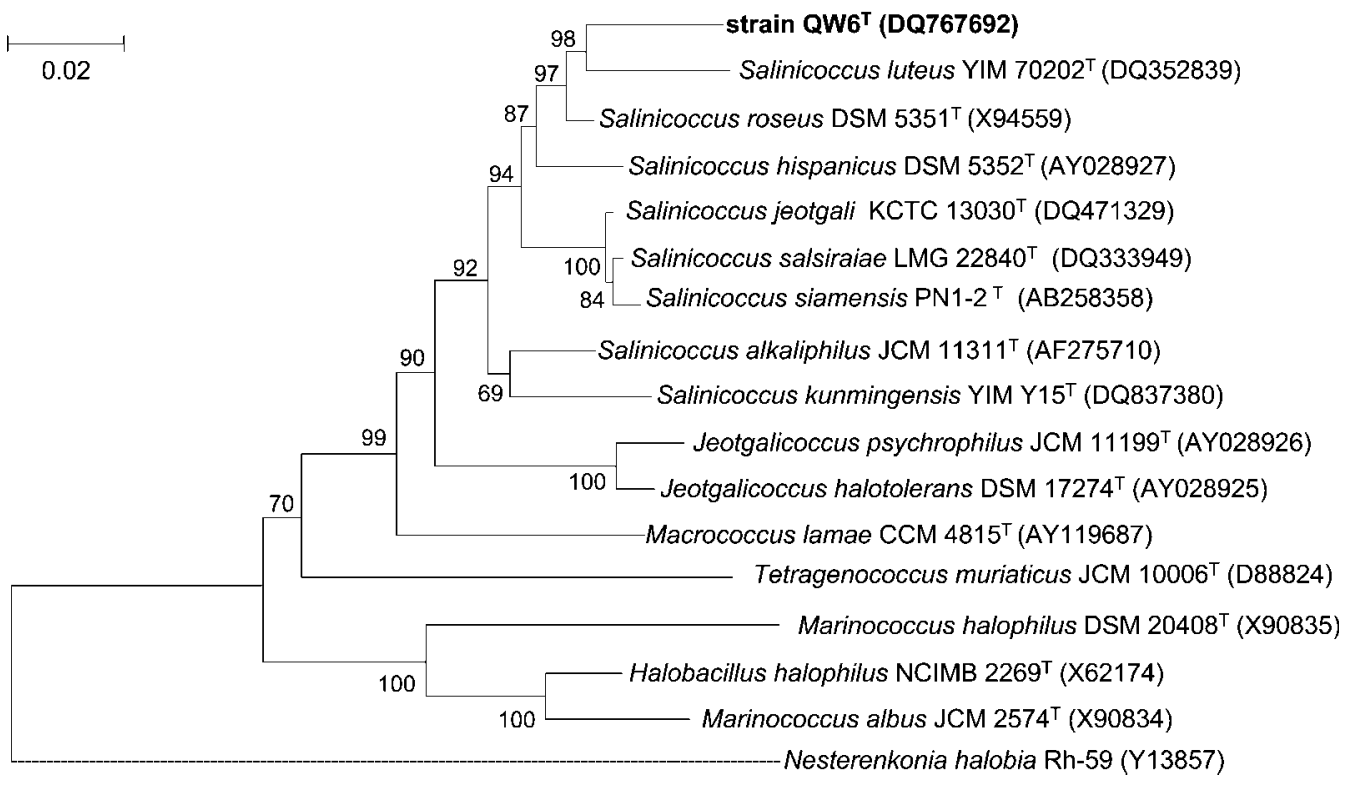

Fig. 2. Neighbour-joining tree showing the relationship between Salinicoccus iranensis sp. nov. OW6 ${ }^{\top}$ and related taxa. Bootstrap values greater than $50 \%$ are indicated. Bar, $2 \%$ estimated sequence divergence. 


\section{Description of Salinicoccus iranensis sp. nov.}

Salinicoccus iranensis (i.ran.en'sis. N.L. masc. adj. iranensis from Iran, where the organism was isolated).

Cells are Gram-positive cocci, $0.8-1.0 \mu \mathrm{m}$ in diameter, occurring singly, in pairs, in tetrads or in clumps. Nonmotile and strictly aerobic. Endospores are not formed. Colonies are round, smooth, slightly convex and orangish pink in colour; no diffusible pigment is produced. Growth occurs in media containing $1.0-25.0 \%(\mathrm{w} / \mathrm{v}) \mathrm{NaCl} ; 10 \%$ $(\mathrm{w} / \mathrm{v})$ is optimal for growth. No growth occurs in the absence of $\mathrm{NaCl}$. The $\mathrm{pH}$ range for growth is 6.5-10.0 (optimum at $\mathrm{pH} 7.5$ ). Growth occurs at $5.0-45.0{ }^{\circ} \mathrm{C}$ (optimum at $35^{\circ} \mathrm{C}$ ). Catalase, oxidase, and Simmons' citrate and indole tests are positive. $\mathrm{H}_{2} \mathrm{~S}$ production and methyl red, Voges-Proskauer and urease tests are negative. Tween 20 is weakly hydrolysed, whereas casein, starch, aesculin, gelatin and Tween 80 are not. Utilizes sucrose, glucose, starch, aesculin, D-mannitol, D-mannose, lactate, dextrin, salicin, inositol and fructose as sole carbon and energy sources. Acid is produced from ( + )-D-glucose and

Table 2. Cellular fatty acid content of cells of strain $\mathrm{QWW} 6^{\top}$ and the type strains of Salinicoccus species

Strains: 1, strain $\mathrm{QW6}^{\mathrm{T}} ; 2$, S. roseus DSM $5351^{\mathrm{T}}$; 3, S. alkaliphilus DSM $16010^{\mathrm{T}}$; 4, S. hispanicus DSM $5352^{\mathrm{T}} ; 5$, S. salsiraiae DSM $19496^{\mathrm{T}}$; 6, S. jeotgali S2R $53-5^{\mathrm{T}}$. Values below $0.6 \%$ are not shown. All data are from this study (cells cultivated on plates of $10 \% \mathrm{MH}$ medium containing $8 \% \mathrm{NaCl}$ at $37{ }^{\circ} \mathrm{C}$ for $24 \mathrm{~h}$ ) apart from data for S. jeotgali S2R53-5 ${ }^{\mathrm{T}}$ (cells cultivated on saline agar for 2 days; Aslam et al., 2007).

\begin{tabular}{|c|c|c|c|c|c|c|}
\hline Fatty acid & 1 & 2 & 3 & 4 & 5 & 6 \\
\hline \multicolumn{7}{|l|}{ Saturated fatty acids: } \\
\hline $\mathrm{C}_{14: 0}$ & 2.9 & 5.2 & 1.7 & 1.5 & 0.9 & 4.4 \\
\hline $\mathrm{C}_{15: 0}$ & 1.3 & 3.1 & 0.9 & 0.7 & & \\
\hline $\mathrm{C}_{16: 0}$ & 8.8 & 11.2 & 3.4 & 3.4 & 3.5 & 10.0 \\
\hline $\mathrm{C}_{18: 0}$ & 2.7 & 3.3 & & 0.7 & & \\
\hline $\mathrm{C}_{19: 0}$ & & 0.7 & & & & \\
\hline $\mathrm{C}_{20: 0}$ & 7.2 & 1.7 & & & & \\
\hline \multicolumn{7}{|l|}{ Unsaturated fatty acids: } \\
\hline $\mathrm{C}_{16: 1} \omega 7 c$ alcohol & 0.9 & 1.1 & 2.3 & 1.3 & & 4.1 \\
\hline $\mathrm{C}_{16: 1} \omega 11 c$ & 1.7 & 1.2 & 1.7 & 0.6 & & 3.6 \\
\hline \multicolumn{7}{|l|}{ Branched fatty acids: } \\
\hline iso- $\mathrm{C}_{14: 0}$ & 4.1 & 6.8 & 5.0 & 3.0 & 1.0 & 3.2 \\
\hline iso- $\mathrm{C}_{15: 0}$ & 23.4 & 20.7 & 24.6 & 27.5 & 17.3 & 22.8 \\
\hline iso- $\mathrm{C}_{15: 1}$ AT5 & & & & 1.3 & & \\
\hline anteiso- $\mathrm{C}_{15: 0}$ & 23.6 & 22.6 & 31.1 & 31.8 & 36.8 & 32.4 \\
\hline iso- $\mathrm{C}_{16: 0}$ & 3.7 & 5.5 & 9.7 & 3.7 & 5.1 & 4.1 \\
\hline iso- $\mathrm{C}_{17: 0}$ & 4.9 & 3.9 & 4.6 & 7.4 & 7.8 & 5.0 \\
\hline iso- $\mathrm{C}_{17: 1} \omega 10 c$ & 1.5 & 0.7 & 2.4 & 3.5 & 5.0 & \\
\hline anteiso- $\mathrm{C}_{17: 0}$ & 4.5 & 3.9 & 6.8 & 6.4 & 14.2 & 6.2 \\
\hline iso- $\mathrm{C}_{19: 0}$ & 1.8 & 1.2 & 0.8 & 0.7 & 1.1 & \\
\hline anteiso- $\mathrm{C}_{19: 0}$ & 0.7 & 0.7 & & & 1.1 & \\
\hline $\begin{array}{l}\text { Unknown fatty acid (ECL } \\
15.668 \text { ) }\end{array}$ & 4.4 & 5.0 & 2.6 & 5.0 & 4.0 & 4.3 \\
\hline
\end{tabular}

fructose, but not from arabinose, maltose, galactose, glycerol, raffinose, D-melibiose, L-rhamnose, lactose or sucrose. Nitrate is reduced. L-Cysteine, L-proline and Lglycine are utilized as sole nitrogen sources, whereas urea, yeast extract, L-arginine, L-ornithine, L-asparagine and Lphenylalanine are not. Susceptible to carbenicillin $(100 \mu \mathrm{g})$, cephalothin $(30 \mu \mathrm{g})$, cefoxitin $(30 \mu \mathrm{g})$, chloramphenicol $(30 \mu \mathrm{g})$, cotrimoxazole $(25 \mu \mathrm{g})$, erythromycin $(15 \mu \mathrm{g})$, neomycin $(30 \mu \mathrm{g})$, nitrofurantoin $(300 \mu \mathrm{g})$ and tetracycline $(30 \mu \mathrm{g})$; resistant to ampicillin $(10 \mu \mathrm{g})$, bacitracin $(10 \mathrm{U})$, clindamycin $(2 \mu \mathrm{g})$, cloxacillin $(5 \mu \mathrm{g})$, gentamicin $(30 \mu \mathrm{g})$, novobiocin $(5 \mu \mathrm{g})$, penicillin $\mathrm{G}(10 \mathrm{U})$, polymyxin $\mathrm{B}(100 \mathrm{U})$, streptomycin $(10 \mu \mathrm{g})$ and tobramycin $(10 \mu \mathrm{g})$; intermediately susceptible to amikacin $(30 \mu \mathrm{g})$ and kanamycin $(30 \mu \mathrm{g})$. Other phenotypic features of this strain are shown in Table 1. The cell wall contains peptidoglycan of the L-Lys-Gly $y_{5}$ type. The major respiratory lipoquinone is MK-6. Predominant fatty acids are iso- $\mathrm{C}_{15: 0}$ and anteiso- $\mathrm{C}_{15: 0}$. The DNA $\mathrm{G}+\mathrm{C}$ content of the type strain is $54.4 \mathrm{~mol} \%$.

The type strain is $\mathrm{QW6}^{\mathrm{T}}\left(=\mathrm{DSM} 18903^{\mathrm{T}}=\mathrm{CCM} 7448^{\mathrm{T}}\right)$, isolated from wastewaters of the textile industry in Qom, Iran.

\section{Acknowledgements}

Financial support for this work was provided by the Research Council, University of Tehran. We are grateful to Dr Jean Euzéby for recommending the proper etymology.

\section{References}

Aslam, Z., Lim, J. H., Im, W.-T., Yasir, M., Chung, Y. R. \& Lee, S.-T. (2007). Salinicoccus jeotgali sp. nov., isolated from jeotgal, a traditional Korean fermented seafood. Int J Syst Evol Microbiol 57, 633-638.

Baron, E. J. \& Finegold, S. M. (1990). Bailey and Scott's Diagnostic Microbiology, 8th edn. St Louis: Mosby.

Bozzola, J. J. \& Russell, L. D. (1999). Electron Microscopy: Principles and Techniques for Biologists, 2nd edn. Sudbury, MA: Jones and Bartlett Publishers.

Cashion, P., Holder-Franklin, M. A., McCully, J. \& Franklin, M. (1977). A rapid method for base ratio determination of bacterial DNA. Anal Biochem 81, 461-466.

Chen, Y.-G., Cui, X.-L., Pukall, R., Li, H.-M., Yang, Y.-L., Xu, L.-H., Wen, M.-L., Peng, Q. \& Jiang, C.-L. (2007). Salinicoccus kunmingensis sp. nov., a moderately halophilic bacterium isolated from a salt mine in Yunnan, south-west China. Int J Syst Evol Microbiol 57, 2327-2332.

De Ley, J., Cattoir, H. \& Reynaerts, R. (1970). The quantitative measurement of DNA hybridization from renaturation rates. Eur $J$ Biochem 12, 133-142.

Felsenstein, J. (1985). Confidence limits on phylogenies: an approach using the bootstrap. Evolution 39, 783-791.

Felsenstein, J. (1993). PHYLIP (phylogeny inference package), version 3.5c. Distributed by the author. Department of Genome Sciences, University of Washington, Seattle, USA.

França, L., Rainey, F. A., Nobre, M. F. \& da Costa, M. S. (2006). Salinicoccus salsiraiae sp. nov.: a new moderately halophilic 
gram-positive bacterium isolated from salted skate. Extremophiles 10, 531-536.

Groth, I., Schumann, P., Weiss, N., Martin, K. \& Rainey, F. A. (1996). Agrococcus jenensis gen. nov., sp. nov., a new genus of actinomycetes with diaminobutyric acid in the cell wall. Int J Syst Bacteriol 46, 234-239.

Harrigan, W. F. \& McCance, M. E. (1976). Laboratory Methods in Food and Dairy Microbiology. London: Academic Press.

Huß, V. A. R., Festl, H. \& Schleifer, K. H. (1983). Studies on the spectrophotometric determination of DNA hybridization from renaturation rates. Syst Appl Microbiol 4, 184-192.

Jukes, T. H. \& Cantor, C. R. (1969). Evolution of protein molecules. In Mammalian Protein Metabolism, vol. 3, pp. 21-132. Edited by H. N. Munro. New York: Academic Press.

Kumar, S. K., Tamura, K. \& Nei, M. (2004). MEGA3: an integrated software for molecular evolutionary genetics analysis and sequence alignment. Brief Bioinform 5, 150-163.

Mata, J. A., Martinez-Conovasa, J., Quesada, E. \& Bejar, V. (2002). A detailed phenotypic characterization of the type strains of Halomonas species. Syst Appl Microbiol 25, 360-375.

Mesbah, M., Premachandran, U. \& Whitman, W. B. (1989). Precise measurement of the $\mathrm{G}+\mathrm{C}$ content of deoxyribonucleic acid by highperformance liquid chromatography. Int J Syst Bacteriol 39, 159-167.

Monciardini, P., Cavaletti, L., Schumann, P., Rohde, M. \& Donadio, S. (2003). Coexibacter woesei gen. nov., sp. nov., a novel representative of a deep evolutionary line of descent within the class Actinobacteria. Int J Syst Evol Microbiol 53, 569-576.

Murray, R. G. E., Doetsch, R. N. \& Robinow, C. F. (1994), Determinative and cytological light microscopy. In Methods for General and Molecular Bacteriology, pp. 21-41. Edited by P. Gerhardt, R. G. E. Murray, W. A. Wood \& N. R. Krieg. Washington, DC: American Society for Microbiology.

Pakdeeto, A., Tanasupawat, S., Thawai, C., Moonmangmee, S., Kudo, T. \& Itoh, T. (2007). Salinicoccus siamensis sp. nov., isolated from fermented shrimp paste in Thailand. Int J Syst Evol Microbiol 57, 2004-2008.

Quesada, E., Ventosa, A., Ruiz-Berraquero, F. \& RamosCormenzana, A. (1984). Deleya halophila, a new species of moderately halophilic bacteria. Int J Syst Bacteriol 34, 287-292.

Saitou, N. \& Nei, M. (1987). The neighbor-joining method: a new method for reconstructing phylogenetic trees. Mol Biol Evol 4, 406-425.

Schleifer, K. H. (1985). Analysis of the chemical composition and primary structure of murein. Methods Microbiol 18, 123-156.
Schleifer, K. H. \& Kandler, O. (1972). Peptidoglycan types of bacterial cell walls and their taxonomic implications. Bacteriol Rev 36, 407-477.

Smibert, R. M. \& Krieg, N. R. (1994). Phenotypic characterization In Methods for General and Molecular Bacteriology, pp. 607-654. Edited by P. Gerhardt, R. G. E. Murray, W. A. Wood \& N. R. Krieg. Washington, DC: American Society for Microbiology.

Stackebrandt, E. \& Goebel, B. M. (1994). Taxonomic note: a place for DNA-DNA reassociation and $16 \mathrm{~S}$ rRNA sequence analysis in the present species definition in bacteriology. Int J Syst Bacteriol 44, 846-849.

Stead, D. E., Sellwood, J. E., Wilson, J. \& Viney, I. (1992). Evaluation of a commercial microbial identification system based on fatty acid profiles for rapid, accurate identification of plant pathogenic bacteria. J Appl Bacteriol 72, 315-321.

Thompson, J. D., Gibson, T. J., Plewniak, F., Jeanmougin, F. \& Higgins, D. G. (1997). The CLUSTAL_X windows interface: flexible strategies for multiple sequence alignment aided by quality analysis tools. Nucleic Acids Res 25, 4876-4882.

Ventosa, A., Quesada, E., Rodríguez-Valera, F., Ruiz-Berraquero, F. \& Ramos-Cormenzana, A. (1982). Numerical taxonomy of moderately halophilic Gram-negative rods. J Gen Microbiol 128, 1959-1968.

Ventosa, A., Marquez, M. C., Ruiz-Berraquero, F. \& Kocur, M. (1990). Salinicoccus roseus gen. nov., sp. nov., a new moderately halophilic Gram-positive coccus. Syst Appl Microbiol 13, 29-33.

Ventosa, A., Marquez, M. C., Weiss, N. \& Tindall, B. J. (1992). Transfer of Marinococcus hispanicus to the genus Salinicoccus as Salinicoccus hispanicus comb. nov. Syst Appl Microbiol 15, 530-534.

Washington, J. A., II \& Sutter, V. L. (1980). Dilution susceptibility test: agar and macro-broth dilution procedures. In Manual of Clinical Microbiology, 3rd edn, pp. 453-458. Edited by E. H. Lennette, A. Balows, W. J. Hausler, Jr \& J. P. Truant. Washington, DC: American Society for Microbiology.

Wayne, L. G., Brenner, D. J., Colwell, R. R., Grimont, P. A. D., Kandler, O., Krichevsky, M. I., Moore, L. H., Moore, W. E. C., Murray, R. G. E. \& other authors (1987). International Committee on Systematic Bacteriology. Report of the ad hoc committee on reconciliation of approaches to bacterial systematics. Int J Syst Bacteriol 37, 463-464.

Zhang, W., Xue, Y., Ma, Y., Zhou, P., Ventosa, A. \& Grant, W. D. (2002). Salinicoccus alkaliphilus sp. nov., a novel alkaliphile and moderate halophile from Baer soda lake in inner Mongolia autonomous region, China. Int J Syst Evol Microbiol 52, 789-793.

Zhang, Y.-Q., Yu, L.-Y., Liu, H.-Y., Zhang, Y.-Q., Xu, L.-H. \& Li, W.-J. (2007). Salinicoccus luteus sp. nov., isolated from a desert soil. Int J Syst Evol Microbiol 57, 1901-1905. 